\title{
Short Communication: Molecular characteristic of taro white cattle based on DNA microsatellite markers
}

\author{
LUH GDE SRI SURYA HERYANI ${ }^{1, \bullet}$, I NENGAH WANDIA ${ }^{1}$, I WAYAN SUARNA ${ }^{2}$, I KETUT PUJA ${ }^{3}$, \\ NI NYOMAN WERDI SUSARI ${ }^{1}$, KADEK KARANG AGUSTINA ${ }^{4}$ \\ ${ }^{1}$ Department of Anatomy, Faculty of Veterinary Medicine, Universitas Udayana. Jl. P.B. Sudirman, Denpasar 80234, Bali, Indonesia. \\ Tel.: +62-361-223791, `email: surya_heryani@yahoo.com \\ ${ }^{2}$ Department of Tropical Forage Research and Development Center, Universitas Udayana. Jl. P.B. Sudirman, Denpasar 80234, Bali, Indonesia \\ ${ }^{3}$ Department of Veterinary Genetics and Reproduction Technology, Faculty of Veterinary Medicine, Universitas Udayana, Jl. P.B. Sudirman, Denpasar \\ 80234, Bali, Indonesia \\ ${ }^{4}$ Department of Veterinary Public Health, Faculty of Veterinary Medicine, Universitas Udayana. J1. P.B. Sudirman, Denpasar 80234, Bali, Indonesia
}

Manuscript received: 24 July 2018. Revision accepted: 13 February 2019.

\begin{abstract}
Heryani LGSS, Wandia IN, Suarna IW, Puja IK, Susari NNW, Agustina KK. 2019. Short Communication: Molecular characteristic of taro white cattle based on DNA microsatellite markers. Biodiversitas 20: 671-675. This research was conducted to assess and characterize the genetics of Taro White cattle. Genetic characterizations of this cattle are essential to conservation and breeding program. A total of 18 samples and 4 pairs of microsatellite DNA markers (BM2113, BM1824, INRA023, and ETH225) were amplified by PCR and the products were run on $8 \%$ bis-Acrylamide gels. All microsatellite markers were successfully amplified with a mean allelic number of 3.25. Means of observed and expected heterozygosity were found to be 0,25 and 0,628 . The Polymorphism Information Content (PIC) values ranged from 0.448 (BM1824) to 0.627 (BM2113) and fixation index were 0.620. The deviation from Hardy-Weinberg equilibrium revealed that Taro White cattle population exhibited significant deviations from Hardy-Weinberg equilibrium (HWE) and possessed a possibility of inbreeding. The microsatellite loci used or focused in the present study further validate their use for evaluation of genetic diversity of Taro White
\end{abstract}

Keywords: Genetic diversity, microsatellite, Taro White Cattle

\section{INTRODUCTION}

Cattle are the animal that can be found in almost all countries in the world (Thornton 2010). Cattle breeds contribute a total number of mammalian breed in the world (Sutarno and Setyawan 2015; Gororo et al. 2018). For most livestock species, Asia is the region have the largest number of cattle (Sugiyama et al. 2003). Indonesia is having four well-recognized breeds (Sutarno and Setyawan 2016; Suwiti et al. 2017), besides numerous populations, that are yet to be characterized and defined. Taro White cattle breed found only in a limited area of Taro village, Tegallalang district, Gianyar, Bali Province (Figure 1). The cattle have a white coat color and they are managed under extensive conditions in a small area and sanctified by the surrounding communities and Balinese society in general (Dharmawan et al. 2010). They play an important role in culture as they are used for rituals. The origin of this cattle is unknown, but people in Taro believed that these cattle to have inhabited the area prior to the arrival of Rsi Markandya, a Mahayogi (High Priest) from Eastern Java who came to Bali on spiritual guidance (Yasa et al. 2015).

The taro white cattle are a unique group with a very small number of population and kept at Taro forest at Tegallalang. Currently, there are only 33 cattle in the area. Based on population and the classifications used by FAO,
Taro White cattle is considered to be in its critical condition (FAO 2007). This breed is considered are at risk of extinction. Losing hallmarks of this breed mean losing of cultural identity as well as losing part of the heritage of humanity. To ensure that this is unique genetic resources are available in the future, conservation can be considered as part of the overall strategy used in order to protect Taro White cattle continually.

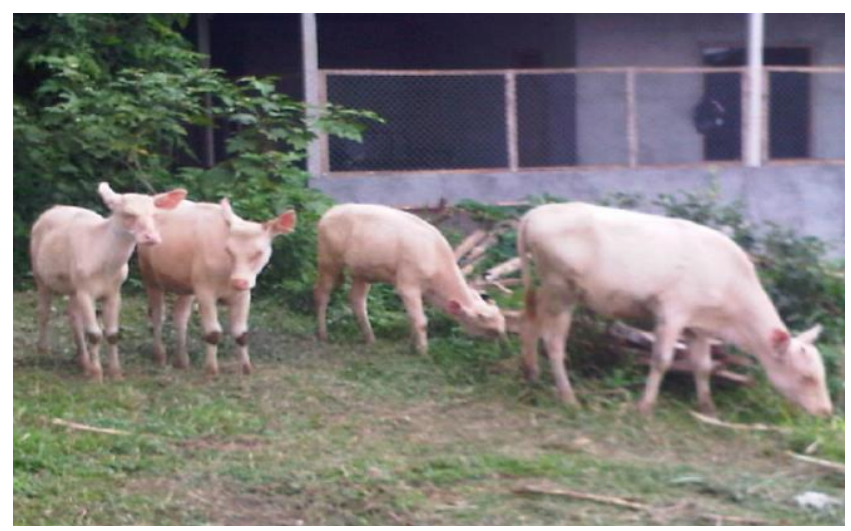

Figure 1. Taro white cattle 
An important strategy in the conservation of these cattle is the dissemination of information on these resources. However, the Taro White cattle breeds are not well classified or are defined with very limited information. Only morphological data available (Heryani et al. 2016), but this lacking, then genetic data is needed for conservation strategies. Genetic characterization of this cattle is therefore necessary, as it is more reliable and the information will be the basis of conservation (Boyazoglu et al. 2005; Adriana et al. 2010).

Genetic characterization can be done by various methods (Amin 2010). Recently is to use molecular markers for characterization which detect the genetic variation at DNA level (Sutarno 2010). Microsatellites are the molecular marker of choice for the genetic characterization of the population because they are highly polymorphic single locus DNA sequences scattering throughout the genome and they easily adapt to the Polymerase Chain Reaction (PCR). Many researchers have used microsatellites to reveal the molecular size of products and allele frequency, the number of alleles and genetic characterization of cattle (Sahlu and Goetsch 2005). DNA microsatellite is best used for identification of a nation as microsatellites are not influenced by the environment (Thilagam et al. 2006). Canon et al. (2001) using 16 microsatellite loci to determine the structure and genetic diversity in 18 European groups of local cattle, coming from Spain, Portugal and France, and were able to differentiate among the cattle, with heterozygosity values between 0.54 to 0.72 and fixation index 0.07 . Information regarding the characterization of these breeds at the molecular level has not been studied yet. therefore, this research became the first. The aim of the present study was to characterize Taro white cattle at a molecular level by means of analysis genetic variability of four microsatellite markers.

\section{MATERIALS AND METHODS}

\section{Sample collection and DNA extraction}

The sample used in this study was kept in small ranches in Taro Village. Blood samples were collected from 18 cattle. Genomic DNA was extracted from blood samples by Purelink® Genomic DNA Kit 50 RXN (Invitrogen) according to the manufacturer's protocol DNA extraction was performed at Molecular Laboratory of Primate Animal Research Center, Udayana University.

\section{Microsatellite analysis}

A total of four microsatellite primers, specific for cattle, were used for characterizing the Taro White cattle breed as recommended by FAO. They were BM1824, BM2113, INRA023, and ETH225. To detect microsatellite polymorphism, all markers were amplified using PCR (Polymerase Chain Reaction). The PCR reaction performed in PCT 100 (MJ Research, Inc. Watertown, Mass, USA) in $12.5 \mu \mathrm{l}$ reaction was using thermocycler PCT 100 (MJ Research, Inc., Watertown, Mass, USA). with the following PCR program; a denaturation for 3 minutes at $94^{\circ} \mathrm{C}$, followed by 30 cycles of denaturation at $94^{\circ} \mathrm{C}$ for 30 seconds, annealing at $55^{\circ} \mathrm{C}$ for 30 second and elongation at $72^{\circ} \mathrm{C}$ for 30 seconds, and extension at $72^{\circ} \mathrm{C}$ for 5 minutes.

Microsatellite DNA amplification product was separated in bis-Acrylamide $8 \%$ gel using an electrophoresis technique for 1 hour 15 minutes or until Bromthymol blue dye reached the bottom of the gel and band visualization was done by silver staining. DNA typing was done by measuring the migration distance of each DNA bands in the gel compared with standard $100 \mathrm{bp}$ DNA ladder (Behl et al. 2007).

\section{Statistical analysis}

Allelic frequencies number of alleles, Ho (observed heterozygosities), $\mathrm{He}$ (expected heterozygosities) and $\mathrm{Ht}$ were estimated for the genotype dataset using Microsatellite toolkit (Park 2001). Hardy-Weinberg equilibrium was also analyzed to determine the random mating in the local population used the fixation index $\left(\mathrm{F}_{\mathrm{IT}}\right)$ followed by $\chi^{2}$ test, with the degree of freedom was 1 , to observe inbreeding occurrence in a population (Nei 1987).

\section{RESULTS AND DISCUSSION}

\section{Results}

The results showed that the four markers have been successfully amplified in the microsatellite loci of Taro White cattle. All markers were highly polymorphic in all populations. Total of 13 alleles were successfully observed from all samples and the number of the allele at each locus varied from 3 (BM1824, INRA023 and ETH225) to 4 (BM2113) alleles, with an average of 3.25 allele diversity ranged from $125 \mathrm{bp}$ (BM2113) to $204 \mathrm{bp}$ (INRA023) (Table.1)

Table 1. The number, size and frequency of allele locus BM1824, BM2113, INRA023 and ETH225

\begin{tabular}{lccc}
\hline Locus & Allele qty. & Allele size & Allele freq. \\
\hline BM1824 & 3 & 180 & 50.00 \\
& & 187 & 44.44 \\
& & 193 & 5.56 \\
BM2113 & 4 & 125 & 41.67 \\
& & 130 & 33.33 \\
& & 136 & 13.89 \\
& & 138 & 11.11 \\
INRA023 & 3 & 198 & 16.67 \\
& & 200 & 55.56 \\
& & 204 & 27.78 \\
ETH225 & 3 & 152 & 22.22 \\
& & 154 & 27.78 \\
& & 156 & 50.00 \\
Total allele & 13 & & \\
Allele diversity & 3.25 & & \\
\hline
\end{tabular}


Table 2. Microsatellite locus amplified in Taro White cattle

\begin{tabular}{lcccccc}
\hline Locus & $\begin{array}{c}\text { Number } \\
\text { of } \\
\text { alleles }\end{array}$ & Allele size & PIC & Ho & He & FIT \\
\hline BM1824 & 3 & $180-193$ & 0.448 & 0.111 & 0.565 & 0.808 \\
BM2113 & 4 & $125-138$ & 0.627 & 0.444 & 0.703 & 0.375 \\
INRA023 & 3 & $198-204$ & 0.517 & 0.222 & 0.603 & 0.638 \\
ETH225 & 3 & $152-156$ & 0.553 & 0.222 & 0.641 & 0.660 \\
Average & 3.25 & & 0.536 & 0.250 & 0.628 & 0.620 \\
\hline
\end{tabular}

Note: PIC: Polymorphism Information Content; Ho: Heterozygosity observed; He: Heterozygosity expected, $\mathrm{H}_{\mathrm{T}}$ : Total Heterozygosity, FIT: Fixation Index.

PIC values ranged from 0.448 (BM1824) to 0.627 (BM2113). The observed heterozygosity (Ho) ranged between 0.0111 (BM1824) and 0.2222 (INRA023 and ETH225). The average value of observed heterozygosity (Ho) and expected heterozygosity (He) were 0.250 and 0.628 respectively and the average value of F IT was 0.620 . The results of microsatellite analysis in terms of the number of the allele, allele size, PIC, and heterozygosity Taro White cattle are presented in Table 2.

The locus BM1824 have three different alleles with the product size are $180 \mathrm{bp}, 187 \mathrm{bp}$, and $193 \mathrm{bp}$. Allele $180 \mathrm{bp}$ being most predominant having $50.0 \%$. The average observed heterozygosity (Ho) and expected heterozygosity (He) were 0.1111 and 0.5651 . The average PIC value was 0.4479 and the fixation index was 0.807 .

The locus BM2113 have four different alleles with the product size are $125 \mathrm{bp}, 130 \mathrm{bp}, 136 \mathrm{bp}$, and 138bp. Allele $125 \mathrm{bp}$ being most predominant having $41.67 \%$ frequency. The average observed heterozygosity (Ho) and expected heterozygosity $(\mathrm{He})$ were 0.444 and 0.703 . The average PIC value was 0.627 and the fixation index was 0.375 .

The locus INRA023 have three different alleles with the product size are $198 \mathrm{bp}, 200 \mathrm{bp}$, and $204 \mathrm{bp}$. Allele $200 \mathrm{bp}$ being most predominant having $55.56 \%$ frequency. The average observed heterozygosity (Ho) and expected heterozygosity $(\mathrm{He})$ were 0.222 and 0.603 . The average PIC value was 0.517 and the fixation index was 0.638 .

The locus ETH225 have three different alleles with the product size are $152 \mathrm{bp}, 154 \mathrm{bp}$, and $156 \mathrm{bp}$. Allele $156 \mathrm{bp}$ being most predominant having $50.00 \%$ frequency. The average observed heterozygosity (Ho) and expected heterozygosity $(\mathrm{He})$ were 0.222 and 0.641 . The average PIC value was 0.553 and the fixation index was 0.660 .

The results of loci investigation (three out of four loci) showed significant Chi-square values suggesting a variation from Hardy-Weinberg Equilibrium (HWE). The loci BM1824, INRA023 and ETH225 with values lower than $0.05(\mathrm{p}<0.05)$, , showed that indicating the deviation of Hardy-Weinberg equilibrium (HWE) revealed that the populations of taro white cattle and the likely occurrence of inbreeding. But at the locus BM2113 show results in accordance with the Hardy-Weinberg equilibrium, with values close to zero $(\mathrm{P}>0.05)$.

\section{Discussion}

Genetic diversity is useful to determine the genetic relationships within and among populations that are fragmented in a population, which can be analyzed with the approach of DNA (Hartl and Clark 2000). One approach to DNA that can be used to analyze genetic diversity is a microsatellite DNA. A number of microsatellite markers used in this study are four markers namely BM1824, BM2113, INRA023, ETH225, and have successfully amplified the population. The Measures of alleles derived from PCR products varies greatly, ranging from a low of $125 \mathrm{bp}$ at the locus of BM in 2113 to a high of $204 \mathrm{bp}$ at the locus INRA023, with a number of alleles ranging from 3 to 4 .

It has been identified as 3 alleles in microsatellite loci BM1824 in Taro white cattle, with a range of allele 180$193 \mathrm{bp}$. Size $180 \mathrm{bp}$ allele is found at the most that is $50.00 \%$. The number and size of the alleles in this study on the same locus (BM1824), are different with Simmental cattle, in which the number of alleles 6 and a size 176190bp (Jevrosima et al. 2009), this is likely due to the Taro white cattle and Simmental cattle are different breeds.

Amplification of the four loci was tested on Taro white cattle that produce no amount of different alleles showed that almost all loci can distinguish genetic resources in Taro white cattle. This suggests that the difference between these microsatellite loci have different levels of diversity. The standard microsatellite marker that can be used for the analysis of genetic diversity is every locus must have at least 3 alleles with sizes ranging from 100-300 bp (Yu et al. 2009).

The number of alleles observed in this study ranged from 3 to 4 with an average of $3.25 \pm 2.77$ allele per locus. The number of the allele in this study was smaller than another study, that showed The number and size of Taro white cattle alleles at these loci, in contrast to Simmental cows, where the number of alleles 9 , and its size is 122142 bp (Jevrosima et al. 2009). Which used the equal number of markers and identified alleles with 6 alleles at the locus ETH225, 7 alleles at the locus BM2113, 6 alleles at the locus INRA023 and 4 alleles at the locus BM1824. The diversity among loci microsatellite alleles frequency in the population of Taro cattle microsatellite loci is presumably because it has a high polymorphic nature. Nei (1987), states that an allele is said to be polymorphic if it has an allele frequency which is equal to or less than 0.99 (99\%). Genetic diversity (genetic polymorphism) is a condition where there is more than one form or kind of genotype in the population. This value of number and allele size reflected the lower level of allelic variability in Taro White cattle population. This study suggested that there has been a decrease in genetic diversity in Taro white cattle due to its small population. Population isolation experienced by these cattle allows no gene flow from outside. A population is said to be in a state of balance if the genotype frequencies and allele frequency constant from generation to generation, where this is caused by the merger of gametes occur randomly in large populations. The balance of genes in a population occur if no mutation, selection, migration and genetic drift (Allendorf et al. 2013). The 
mean value of observed heterozygosity (Ho) and expected heterozygosity $(\mathrm{He})$ were 0.250 and 0 . 628. The mean observed heterozygosity recorded in the present study on Taro White cattle was lower than those reported for Sumba Ongole cattle (Agung et al. 2015) and Simmental cattle (Jevrosima et al. 2010). The difference between the values of Ho and He can be used as an indicator of an imbalance in the population genotype (Tambasco et al. 2003).

Four alleles in microsatellite locus BM2113 on of Taro cattle have been identified, with a range of alleles 125-138 bp. Size $125 \mathrm{bp}$ allele is found at the most that is $41.67 \%$. This locus has the highest number of alleles compared to other loci, a high diversity at these loci may be influenced by the level of mutation (Jevrosima et al. 2009).

The number of alleles in the locus INRA023 is smaller compared to similar study in Bali cattle. Four alleles were identified with the highest allele frequency on Bali cattle in these loci is $46 \%$ and the value of heterozygosity of 0.35 (Winaya et al. 2005), whereas in Taro white cattle on the same locus is only identified 3 alleles, with heterozygosity value of 0.22 . This suggests that the genetic diversity in Taro white cattle is lower than the Bali cattle.

In ETH225 microsatellite loci in Taro white cattle successfully been identified to have a number of 3 alleles with a range of $152-156 \mathrm{bp}$. Size $156 \mathrm{bp}$ alleles found at the most that is $50.00 \%$. Research on Bali cattle with the same locus (ETH225) successfully been identified to have 7 allele alleles size between 149-165bp, with the highest frequency of on alleles $165 \mathrm{bp}$ in the amount of $40.0 \%$ and average heterozygosity of 0.717 (Alwiyah 2015).

The results showed that the genetic diversity of Bali cattle is higher than Taro white cattle, may have been a decrease in the diversity of on Taro white cattle as the result of the isolation of cattle so that the gene flow is low and problems with inbreeding. Bennett (2000) states that genetic diversity due to the variations in the number of repetitions of the sequence of the alkali, where differences emerged regarded as different alleles. The different alleles are caused by differences in the number of alkali repetitions.

Heterozygosity is one of the parameters that can be used to measure the level of genetic diversity in a population. Value heterozygosity ranges from zero to one. When the value is close to zero then it is said that heterozygosity is low, it may endanger the sustainability of a species or population (Nozawa et al. 1996; Tanabe et al. 1999). And if the value is close to one then it is said to be high heterozygosity. The higher the value of heterozygosity in a population, the higher the incidence of outbreeding (Nei 1987). Genetic diversity within a breed expressed as average heterozygosity (Metta et al. 2004; Hartati et al. 2010).

Based on the Ho value and PIC, the microsatellite loci BM2113 highest value Ho is 0.444 and the highest value of PIC is 0.627 . BM2113 microsatellite loci (44\%) is the most informative loci (heterozygosity calculated directly with the highest value), and microsatellite loci least-informative (heterozygosity calculated directly lowest) is a BM1824 microsatellite loci $(11 \%)$. The average heterozygosity of Taro white cattle in this study of 0.250 indicates a very low genetic variation in Taro white cattle. Javanmard et al. (2005) state that heterozygosity values below 0.5 indicate low variations of a gene in the population.

The highest level of heterozygosity on locus BM2113 Taro white cattle $(0.444)$ is approximately equal to the previous research, in which Metta et al. (2004) have done on Ongole and Deoni breeds which obtained heterozygosity value of 0.46 and 0.50 , with amplification of 10 microsatellite loci. Taro cattle heterozygosity level is higher than the research done by Hartati et al. (2010) in cattle PO (Ongole breed) with a value of heterozygosity of 0.196 with amplification of 6 microsatellite loci. Meanwhile, if compared to the research done by Agung et al. (2015) in cattle SO (Sumba Ongole) with a value of heterozygosity of $80 \%$ by a total of 12 microsatellite loci amplification, and research done by Jevrosima et al. (2009) on Simmental cattle, with a value of 0.77 by amplification heterozygosity of 11 microsatellite loci, and as compared to cattle Aceh and Bali cattle that have a heterozygosity of value of 0.70 and 0.80 (Abdullah et al. 2008), then heterozygosity of Taro white cattle is the third lower than the previous researches. The low heterozygosity of Taro white cattle is due to inbreeding.

The significant difference between the average value of heterozygosity observation $(0.250)$ and the average value of heterozygosity expectations (0.628) on microsatellite loci used in this study and the low value of Ho indicates any deviation from the equilibrium Hardy-Weinberg (Machado et al. 2003). The difference between the values of Ho and He can be used as an indicator of an imbalance in the population genotype (Tambasco et al. 2003).

Average PIC value in this study was 0.536 . The mean PIC value recorded in the present study was lower than those reported in Sumba Ongole breeds (Agung et al. 2015). PIC value greater than 0.5 (PIC>0.5) indicated that microsatellite loci used in this study were very informative to detect the genetic diversity of the population. The highest PIC value on this study was 0.627 on microsatellite loci BM2113, while the value of the lowest PIC is at 0.448 on microsatellite loci BM1824. The low value of the PIC in the locus BM1824 in this study could be caused by several factors such as: number of alleles, assortative mating, Wahlund effects, the selection of heterozygosity, inbreeding or a combination of all factors (Cervini et al. 2006).

Hardy-Weinberg equilibrium test was used to predict whether the population is stable or not (Tambasco et al. 2003). In this study, the observed genotype was producing significant Chi-square value. It is meant, the population studied was not in Hardy-Weinberg equilibrium. The deviation of the loci from equilibrium may be due to many causes such as genetic drift and small sample size.

Fixation index $\left(\mathrm{F}_{\mathrm{IT}}\right)$ of four microsatellite loci ranged from 0.375 to 0.808 approached a value of 1 . It indicated that there was a deviation from Hardy-Weinberg equilibrium. The results of this study were different from previous studies in cattle in Banteng with $\mathrm{F}_{\mathrm{ST}}$ close to zero $(-0.0207)$, and P>0.05. Similarly, the Simmental cattle from Serbia using the same microsatellite loci as this research showed the value of $\mathrm{P}>0.05$ in accordance with 
the Hardy-Weinberg equilibrium, this $\mathrm{F}_{\mathrm{ST}}$ difference could be due to species differences.

The negative effects of inbreeding will greatly affect a small population, such as the decrease in diversity, the emergence of lethal genes and fixation of some alleles in the population so that the animals become monomorphic and experience a decreased ability to evolve or to adapt to the environment. Declining population is also caused by fragmentation of habitat which would cause the loss of gene flow (the gene flow) and increased genetic drift and inbreeding (mating inbreeding) (Frankham et al. 2004).

In conclusion, from the present study, it was concluded that these markers used were successfully amplified and proved very useful for genetic investigations in Taro White cattle. Taro White cattle possessed a low level of genetic diversity. In the future, information in this study will be useful for the formulation of effective conservation strategies.

\section{ACKNOWLEDGEMENTS}

The authors are thankful to the Kelompok Masyarakat Penyelamat Lembu Putih, Village of Pekraman Taro Kaja, Sub-district of Tegalalang, Gianyar District, Bali, Indonesia for providing the facilities for this research.

\section{REFERENCES}

Adriana MA, de Guimarães SEF, Pereira CS, Lopes PS, Rodrigues MT, Machado TMM. 2010. Paternity in Brazilian goats through the use of DNA microsatellites. R Bras Zootec 5: 1011-1014.

Agung PP, Anwar S, Wulandari AS, Sudiro A, Said S, Tappa B. 2015 The potency of Sumba Ongole (SO) cattle; a study of genetic characterization and carcass productivity. J Indonesian Trop Anim Agric 40 (2): 71-78.

Allendorf FW, Luikart G, Aitken SN. 2013. Conservation and the genetics of populations. Wiley-Blackwell, Oxford, UK.

Alwiyah. 2015. Identifikasi Keragaman DNA Mikrosatelit pada Sapi Bali di Pulau Bali dan Di Pulau Nusa Penida [Thesis]. Departemen Ilmu Produksi dan Teknologi Peternakan, Fakultas Peternakan, Institut Pertanian Bogor, Bogor. [Indonesian]

Amin M. 2010. Intervention of genetic flow of the foreign cattle toward diversity of phenotype expressions of local cattle in the district of Banyuwangi. Biodiversitas 11 (2): 69-74

Behl JD, Verma NK, Behl R, Mukesh M, Ahlawat SPS. 2007. Characterization of genetic polymorphism of the bovine lymphocyte antigen DRB3.2 locus in Kankrej Cattle (Bos indicus). J Dairy Sci 90 2997-3001.

Bennet P. 2000. Microsatellites. Mol Pathol (J Clin Pathol) 53: 177-183.

Boyazoglu J, Hatziminaoglou I, Morand-Fer P. 2005. The role of the goat in society: past and perspectives for the future. Small Rum Res 60: 13-23.

Cervini M, Henrique-Silva, Mortari N, Matteucci E. 2006. Genetic variability of 10 microsatellite markers in the characterization of Brazilian Nellore cattle (Bos indicus). Genet Mol Biol 29: 486-490.

Dharmawan NS, Budaarsa K, Budiasa IKM, Suryani NN. 2010. Pelayanan kesehatan pada sapi putih di Desa Taro Gianyar. Udayana Mengabdi 9 (2): 104-107. [Indonesian]

FAO. 2007. Inter-department working group. climate change in agriculture, forestry and fisheries: Perspective, Framework and Priorities. Food and Agriculture Organization, Rome, Italy.
Frankham R, Ballou JD, Briscoe DA. 2004. A Premier of conservation genetics. Cambridge University Press, Cambridge, UK

Gororo E, Makuza SM, Chatiza FP, Chidzwondo F, Sanyika TW. 2018 Genetic diversity in Zimbabwean Sanga cattle breeds using microsatellite markers. S A J Anim Sci 48 (1): 128-141.

Hartl DL, Clark AG. 2000. Principles of Population Genetics, 3rd ed. Sinauer Associates, Inc. Sunderland, MA.

Heryani LGSS, Wandia IN, Suarna IW, Puja IK. 2016. Morphometric characteristics of the Taro white cattle in Bali. Global Veterinaria 16 (3): 215-218.

Javanmard, A, Asadazadeh, N, Banabazi, M.H, Tavakolian, J. 2005. The allele and genotype frequencies of bovine pituitary-specific transcription factor and leptin genes in Iranian cattle and buffalo populations using PCR-RFLP. J Iranian Biotechnol. 3: 104-108.

Jevrosima S, Stanimirovic Z, Dimitrijevic V, Maletic M. 2010. Evaluation of 11 microsatellite loci for their use in paternity testing in Yugoslav Pied cattle (YU Simmental cattle). Czech J Anim Sci 55 (6): 221-226.

Machado MA, Schuster I, Martinez ML, Campos AL. 2003. Genetic diversity of four cattle breeds using microsatellite markers. R Bras Zootec 32 (1): 93-98.

Metta, M, Kanginakudru, S, Gudisewa, S, Nagaraju, J. 2004. Genetic characterization of the Indian cattle breeds, Ongole and Deoni (Bos indicus), using microsatellite markers - a preliminary study. BMC Genetics 5 (16): 1-5.

Nei M. 1987. Molecular evolutionary genetics. Columbia University Press, New York

Nozawa K, Shotake T, Kawamoto Y, Tanabe Y. 1996. Population genetics of Japanese monkeys; II. Blood protein polymorphism and population structure. Primate 23 (2): 252-271.

Park SDE. 2001. Trypanotolerance in West African cattle and the population genetic effects of selection. Ph.D. Thesis, University of Dublin.

Sahlu T, Goetsch AL. 2005. A foresight on goat research. Small Rum Res 60: 7-12.

Sugiyama M, Iddamalgoda A, Oguri K, Kamiya N. 2003. Development of Livestock Sector in Asia: An Analysis of Present Situation of Livestock Sector and Its Importance for Future Development. Bull Gifu Municipal Women's Junior College 52 (3): 1-9.

Sutarno. 2010. Genetic variations among Indonesian native cattle breeds based on polymorphisms analysis in the growth hormone loci and mitochondrial DNA. Biodiversitas 11 (1): 1-4

Sutarno, Setyawan AD. 2015. Review: Genetic diversity of local and exotic cattle and their crossbreeding impact on the quality of Indonesian cattle. Biodiversitas 16 (2): 327-354.

Sutarno, Setyawan AD. 2016. Review: The diversity of local cattle in Indonesia and the efforts to develop superior indigenous cattle breeds. Biodiversitas 17 (1): 275-295.

Suwiti NK, Besung INK, Mahardika GN. 2017. Factors influencing growth hormone levels of Bali cattle in Bali, Nusa Penida, and Sumbawa Islands, Indonesia. Vet World 10 (10): 1250-1254.

Tambasco DD, Paz CCP, Tambasco-Studart M, Pereira AP, Alencar MM, Freitas AR, Coutinho LL, Packer IU, Regitano CA. 2003. Candidate genes for growth traits in beef cattle cross Bos taurus $x$ Bos indicus. J Anim Breed Genet 120: 51-56.

Tanabe Y, Yokoyama H, Murakami J, Kano H, Tanawaki O, Okabayashi H, Maeda Y, Koshimoto C, Nozawa K, Tumennasan K, Dashnyam KB, Zhanchiv T. 1999. Polymorphisms of the plumage colors, the skin variations and blood proteins in the native chickens in Mongolia. Rep Soc Res Native Livestock 17 (2): 139-153.

Thornton PK. 2010. Livestock production: recent trends, future prospects. Philos Trans R Soc Lond B Biol Sci 365 (1554): 2853-2867.

Winaya, A, Muladno, Tappa, B. 2005. Panel 16 Lokus mikrosatelit untuk deteksi polimorfisme dan hubunganfilogenetik pada genom sapi. Media Peternakan 24 (2): 81-88. [Indonesian]

Yu Q, Luo J, Han X, Zhu YZ, Chen C, Liu JX, Sheng H. 2009. Genetic diversity and relationships of 10 Chinese goat breeds in the middle and western China. Small Rum Res 82 (2-3): 88-93.

Yasa, I.M.R, Adijaya, I.n, Wirawan, P.A.K. 2015. Potensi dan permasalahan pengembangan sapi taro (sapi Bali Putih) di Desa Taro Kabupaten Gianyar Bali. Proc. Seminar Nasional Sumber Daya Genetik Pertanian Pp: 425-431. [Indonesian] 